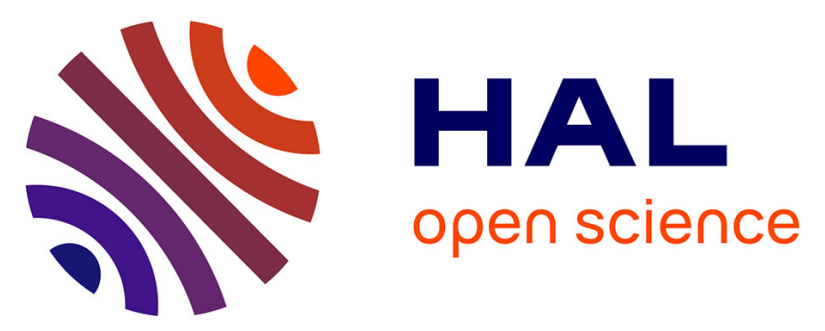

\title{
Optimization of lactic acid production using immobilized Lactobacillus Rhamnosus and carob pod waste from the Lebanese food industry
}

Hajar Bahry, Rawa Abdalla, Agnès Pons, Samir Taha, Christophe Vial

\section{- To cite this version:}

Hajar Bahry, Rawa Abdalla, Agnès Pons, Samir Taha, Christophe Vial. Optimization of lactic acid production using immobilized Lactobacillus Rhamnosus and carob pod waste from the Lebanese food industry. Journal of Biotechnology, 2019, 306, pp.81 - 88. 10.1016/j.jbiotec.2019.09.017 . hal03488625

\section{HAL Id: hal-03488625 \\ https://hal.science/hal-03488625}

Submitted on 21 Dec 2021

HAL is a multi-disciplinary open access archive for the deposit and dissemination of scientific research documents, whether they are published or not. The documents may come from teaching and research institutions in France or abroad, or from public or private research centers.
L'archive ouverte pluridisciplinaire HAL, est destinée au dépôt et à la diffusion de documents scientifiques de niveau recherche, publiés ou non, émanant des établissements d'enseignement et de recherche français ou étrangers, des laboratoires publics ou privés.

\section{(ㄷ)(1) $\$$}

Distributed under a Creative Commons Attribution - NonCommerciall 4.0 International 
1 Optimization of Lactic Acid Production Using Immobilized Lactobacillus Rhamnosus and

2 carob Pod waste from the Lebanese Food Industry

3

4 Hajar Bahry $^{1,2^{*}}$, Rawa Abdalla ${ }^{2}$, Agnès Pons $^{1}$, Samir Taha ${ }^{2}$, Christophe Vial $^{1}$

${ }^{1}$ Université Clermont Auvergne, CNRS, Sigma Clermont, Institut Pascal, F-63000, ClermontFerrand, France

$8 \quad{ }^{2}$ Lebanese University; Doctoral school for sciences and technology; AZM Centre for research in 9 biotechnology and its applications; Laboratory of applied biotechnology for biomolecules, 10 biotherapy and bioprocess; El mitein street, Tripoli, Lebanon. 
Abstract

The valorization of a solid carob waste from the Lebanese industry was investigated by optimizing the production of lactic acid using immobilized Lactobacillus rhamnosus in alginate beads and response surface methodology. The results showed that $\mathrm{pH}$ and alginate concentration had a significant effect on the production of lactic acid. The fermentation of non-enriched carob waste juice needed an additional nitrogen source to improve lactic acid production and yield. From extracts with $65 \mathrm{~g} / \mathrm{L}$ sugars, the optimum conditions were found to be $2 \%$ for the concentration of alginate, $4 \%$ bacteria cells entrapped in beads, $80 \mathrm{rpm}$ agitation speed and $\mathrm{pH}$ 6.4. Lactic acid concentration obtained under these conditions was $22 \mathrm{~g} / \mathrm{L}$ with a yield of $76.9 \mathrm{~g} / \mathrm{g}$ consumed sugar and a productivity of $1.22 \mathrm{~g} / \mathrm{L} / \mathrm{h}$. The use of invertase pretreatment increased lactic acid concentration from 22 to $40 \mathrm{~g} / \mathrm{L}$, but reduced yield at $66.6 \%$. Finally, cells immobilized in alginate beads could be used for at least five successive cycles.

Keywords: carob by-product; cell immobilization; lactic acid; Lactobacillus rhamnosus; response surface methodology

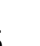

7 


\section{Introduction}

The carob tree (Ceratonia siliqua) belongs to the family of leguminous plants that are grown in the Mediterranean regions (ZENGIN et al., 2008). This is often used as an ornamental plant and in the reforestation of areas damaged by erosion or desertification, given its low cultivation requirements and its tolerance of poor soils (Haddarah et al., 2013). The carob fruit consists of pulp and seeds. With a content of $64 \%$, the carob pulp is particularly rich in sugar, richer than sugar cane and sugar beet (Haankuku et al., 2015; Limtong et al., 2007), and is currently used as a substitute for cacao. In recent years carob pulp has been used to produce value-added products such as mannitol, citric acid and pullulan by fermentation, while the seeds are used for the extraction of galactomannan to obtain locust bean gum (Haddarah et al., 2013).

Lactic acid is a valuable chemical platform that has extensive applications in food, cosmetics, pharmaceutical and chemical industries. Demand for lactic acid increases each year by 5 to $8 \%$ (Yadav et al., 2011). One of the main applications of lactic acid is its capacity to form polylactic acid (PLA), a polymer of great interest (Tian et al., 2018). The demand for PLA increases, while its production is only 450,000 tons per year (Okano et al., 2010). Lactic acid can be produced by chemical or fermentation routes. The chemical pathway leads to the production of a racemic mixture of DL-lactic acid, which increases the cost of separation, while fermentation leads to the production of D- or L-lactic acid depending on the organism used, and opens the opportunity to use cheaper substrates with low energy consumption and to develop a more environment-friendly process (Zhao et al., 2016). In general, fermentation is carried out using free cells, but the immobilization of cells sometimes improves productivity (Zhao et al., 2016). In addition, in relation with free cells, immobilization offers several advantages: namely, a reduced susceptibility to contamination, a decrease in substrate/product inhibition, and cell reuse in recycling steps. Calcium alginate is the most commonly used immobilization matrix (Zhao et al., 
2016) . Idris and Suzanna (Idris and Suzana, 2006) investigated the production of lactic acid from pineapple waste using Lactobacillus delbrueckii immobilized in alginate. Similarly, Sirisansaneeyakul et al.(Sirisansaneeyakul et al., 2007) studied the optimization of lactic acid production by immobilization of Lactococcus lactis. On the other hand, several alternative immobilization matrices are available, such as calcium pectate and chemically-modified chitosan gels (Kourkoutas et al., 2005). Zhao et al.(Zhao et al., 2016) found that the immobilization of $L$. rhamnosus in mesoporous silica-based material increased the fermentation efficiency by $4.1 \%$ over free cells.

In Lebanon, carob molasses, called "dibs", is industrially produced from carob pods and widely consumed as a sweetener. The carob bean juice used for the preparation of molasses is obtained by two successive steps of maceration of carob pods cut into pieces of size close to $5 \mathrm{~mm}$. The solid waste from this preparation is either discharged or used for animal feed. This waste has demonstrated its interest due to its high sugar content (44\% of dry matter), and its ability to be fermented in bioethanol of second generation by Saccharomyces cerevisiae (Bahry et al., 2017). The only work investigating lactic acid production from carob juice has been carried out by Turhan et al.(Turhan et al., 2010a). Conversely, no data can be found on the lactic acid production from carob waste which is less rich in sugar. In addition many nutrients could be removed in the dibs preparation.

Thus, the purpose of this work is to explore another efficient route to valorize the residual carbohydrates of this carob waste by producing lactic acid using immobilized Lactobacillus rhamnosus in alginate beads, which differs from Turhan et al.(Turhan et al., 2010a) who worked directly on pods, using Lactobacillus casei in the liquid phase. The factors influencing the production, such as $\mathrm{pH}$, alginate concentration, pre-culture volume and agitation speed were optimized using response surface methodology (RSM), as well as the number of possible 
fermentation cycles using the same beads.

104

105

\section{Materials and methods}

\subsection{Strain}

The strain Lactobacillus rhamnosus ATCC 53103 was grown at $37^{\circ} \mathrm{C}$ for 48 hours in a medium containing $20 \mathrm{~g}$ of glucose, $4 \mathrm{~g}$ of yeast extract, $0.2 \mathrm{~g}$ of $\mathrm{MgSO}_{4} \cdot 7 \mathrm{H}_{2} \mathrm{O}, 0.05 \mathrm{~g}$ of $\mathrm{MnSO}_{4} \cdot 7 \mathrm{H}_{2} \mathrm{O}$,

$0.5 \mathrm{~g}$ of $\mathrm{K}_{2} \mathrm{HPO}_{4}, 5 \mathrm{~g}$ of sodium acetate, and $0.5 \mathrm{~g}$ of $\mathrm{KH}_{2} \mathrm{PO}_{4}$ per liter of deionized water. The culture was stored at $4^{\circ} \mathrm{C}$ and subcultured bi-weekly in order to maintain viability. For a longterm storage, stock cultures were maintained in $20 \%$ glycerol at $-80^{\circ} \mathrm{C}$.

\subsection{Extraction of sugars from carob waste}

Carob waste $(2.5 \mathrm{~cm}$ size $)$ issued from molasses preparation was used in this work. Residual sugar extraction was obtained by maceration at room temperature for a liquid/solid ratio (L/S=3), without stirring for 90 minutes (Bahry et al., 2017). The concentration of total sugars in the juice was $65 \mathrm{~g} / \mathrm{L}(54 \pm 2 \%$ saccharose, and $46 \pm 2 \%$ hexose, among which glucose and fructose are the most abundant).

\subsection{Immobilization of Lactobacillus rhamnosus}

Inoculum was prepared in the MRS medium (de Man, Rogosa and Sharpe) 24 hours before the fermentation step. Three volumes of pre-culture relative to the volume of work in the reactor (2, 4 and $6 \%$ ) were used for the immobilization in alginate beads. After centrifugation in $50 \mathrm{~mL}$ sterile tubes at $3800 \mathrm{rpm}$ and $4^{\circ} \mathrm{C}$ for $20 \mathrm{~min}$, the pellet was mixed with $20 \mathrm{~mL}$ of alginate solution prepared in three concentrations (2, 3 and 4\%). The bacteria were encapsulated in 
alginate beads by the method of extrusion/gelation of the previously prepared solution using a pump (Gilson-Minipuls 2, France) and a syringe needle (type 20G, 0.9x40 mm) in 4\% (w/w)

$\mathrm{CaCl}_{2}$ solution, leading to the production of beads of $5 \mathrm{~mm}$ approximate diameter. Then, the beads were left for 4 hours, and washed with a sterile $0.85 \% \mathrm{NaCl}$ solution to remove nonadherent cells and the excess of calcium and chloride ions.

\subsection{Batch fermentation}

The fermentation was carried out in a 500-mL volume reactor, with a working volume of 400 $\mathrm{mL}$. The carob juice was either used alone as unenriched carob waste (UECW), or supplemented with yeast extract, $10 \mathrm{~g} / \mathrm{L}$; MgSO4 7H2O, $0.5 \mathrm{~g} / \mathrm{L}$; MnSO4 H2O, 0.03 g/L; K2HPO4, 3 g/L; CH3COONa H2O, 2g/L and Tween $80,1 \mathrm{~mL} / \mathrm{L}$, then denoted enriched carob waste (ECW). The fermentation medium was sterilized in the reactor at $121^{\circ} \mathrm{C}$ for 20 minutes. The alginate beads were transferred to the reactor in a sterile manner. Temperature was set at $37^{\circ} \mathrm{C}$ for all the tests and $\mathrm{pH}$ was adjusted by automatic addition of $5 \mathrm{M} \mathrm{NaOH}$. Lactic acid fermentation was studied for $24 \mathrm{~h}$ and followed by sampling every $2 \mathrm{~h}$ during the first $12 \mathrm{~h}$ and then every $6 \mathrm{~h}$. Samples were analyzed for the determination of lactic acid and residualsugars.

In order to test the ability of reuse alginate beads, several batch fermentation runs were carried out in the reactor using the same beads. After $24 \mathrm{~h}$, the fermentation broth was removed and replaced by the same volume of sterile carob juice. Samples were taken for the analysis of lactic acid and residual sugars. To convert sucrose extracted from carob waste into monosaccharides, technical invertase from baker's yeast (S. cerevisiae) of $60 \mathrm{U} / \mathrm{mg}$ enzyme activity was employed at $55^{\circ} \mathrm{C}$ and $\mathrm{pH} 5.5$.

\subsection{Chemical analysis}

Lactic acid concentration was determined using an HPLC device. The apparatus (HPLC 1260 Infinity Quaternary LC system, from Agilent Technology, USA) was equipped with two ion 
exclusion columns connected in series (Rezex ROA 300X7.8 mm, Phenomenex, USA). The mobile phase was a $2 \mathrm{mM}$ sulfuric acid solution, in ultrapure water (Millipore, MilliQmore), continuously degassed, and flow rate was fixed at $0.7 \mathrm{~mL} / \mathrm{min}$. Lactic acid was detected using a refractometer (HP 1100 series, Agilent Technologies, USA). Before analysis, samples were deproteinized to prevent clogging of the column. This was carried out as follows: $250 \mu \mathrm{L}$ of barium hydroxide solution $\left(\mathrm{BaOH}_{2}, 0.3 \mathrm{M}\right)$ and $250 \mu \mathrm{L}$ of zinc sulfate solution $\left(\mathrm{ZnSO}_{4} \cdot 7 \mathrm{H}_{2} \mathrm{O}, 5 \%\right.$ w/v) were added to a $2 \mathrm{~mL}$ sample, which caused the precipitation of proteins; after centrifugation for $5 \mathrm{~min}$ at $10,000 \mathrm{rpm}$, the supernatant was finally filtered using a cellulose acetate syringe filter $(0.45 \mu \mathrm{m})$.

Total sugars were determined using the method of Dubois et al.(Dubois et al., 1956), and reducing sugars were analyzed by the DNS method of Miller (Miller, 1959).

\subsection{Experimental design and statistical analysis}

Experiments were defined using the Design of Experiments (DOE) methodology. For the optimization of fermentation conditions, response surface methodology (RSM) was applied. Four factors were studied:

- Alginate concentration (A): the range chosen was between 2 and 4\%, according to Idris and Suzana (Idris and Suzana, 2006), because for a concentration lower than $1 \%$, the beads are easily broken, whereas a too high concentration causes a delay in sugar consumption by bacteria.

- $\mathrm{pH}(\mathrm{B})$ : the range was fixed between 4.5 and 6.5 which is the optimal $\mathrm{pH}$ range for the growth of Lactobacillus (Nancib et al., 2001).

- Agitation speed (C): the range was between 50 and $150 \mathrm{rpm}$ to maintain sufficient mass 
transfer, without breaking the beads.

- Amount of bacteria Cells Entrapped in Beads, referred to as ACEB (D): this amount ranged between 2 and 6\%, which is classical in alginate beads (Ercan et al., 2013).

The minimum and maximum values of these four main factors and their coded levels are summarized in Table 1. A four-factor Box-Behnken design was applied to examine the relationship between one or more response variables and for process optimization (Box and Behnken, 1960). This included 27 runs, including 3 replications of the center point. The response variables were the amount of lactic acid produced $(\mathrm{P}, \mathrm{g} / \mathrm{L})$, the yield (YP/S, \%), and the maximum production rate $(\mathrm{QP}, \mathrm{g} / \mathrm{L} / \mathrm{h})$.

The free software environment R (Team, 2014) was used for the creation and analysis of experimental designs and multiple comparison. These were analyzed using ANOVA. Parameters with a p-value (p) of 0.05 or less were considered significant.

\section{Table 1}

\section{Results and discussion}

\subsection{Preliminary experiments}

Preliminary experiments involving the carob waste highlighted that Lactobacillus was able to use saccharose or glucose as the substrate when a single carbon source was used. Conversely, when saccharose and glucose were added simultaneously, only the hexose was consumed. As carob waste extracts contains $35 \mathrm{~g} / \mathrm{L}$ and $30 \mathrm{~g} / \mathrm{L}$ saccharose and hexoses, respectively, this shows that L. rhamnosus prefers monosaccharides as the substrate and that metabolic adaptation from glucose to saccharose is not rapid.

\subsection{Analysis of the experimental design}

\subsubsection{ANOVA and model assessment}


The experimental results of Box-Behnken design are summarized in Table 2. This clearly displays a significant evolution of lactic acid production P (from 15 to $22 \mathrm{~g} / \mathrm{L}$ ), yield YP/S (from 65.0 to $77 \%$ ) and productivity $\mathrm{Q}_{\mathrm{P}}$ (from 0.45 to $1.22 \mathrm{~g} / \mathrm{L} / \mathrm{h}$ ) as a function of the four main factors. A quadratic model with interactions was applied to fit experimental data. The ANOVA tables for the three response variables are summarized in Table 3. The determination coefficient $\mathrm{R}^{2}$ is satisfactory for $\mathrm{P}$ and $\mathrm{QP}, \mathrm{R}^{2}=0.941,0.947$, respectively. Conversely, it is weak for $\mathrm{YP} / \mathrm{S}$, about 0.77. In addition, the lack-of-fit of the model is statistically significant only for YP/S, which implies that the linear model is not adapted for fitting the evolution of this parameter. Another information that arises from Table 3 is that many predictors do not play a significant role among the interaction and the quadratic terms, so that the models can be significantly reduced to a few influential predictors. A descending method was applied: this consists in removing iteratively the predictor with the highest $\mathrm{p}$-value until all the predictors are statistically significant.

\section{Table 2}

The reduced models are summarized in Table 4 for $\mathrm{P}$ and QP, while no significant model could be deduced for YP/S, as expected from Table 3. $\mathrm{R}^{2}$ was 0.87 and 0.92 for $\mathrm{P}$ and $\mathrm{QP}$, respectively, which is satisfactory. Finally, A, B, the quadratic term $\mathrm{B}^{2}$ and the interaction $\mathrm{AD}$ (interaction between alginate concentration and the Amount of bacteria Cells Entrapped in Beads) exhibited a significant effect on $\mathrm{P}$, while $\mathrm{D}$ and the same predictors were significant on QP.

The final model equation for acid lactic production based on coded levels was:

$\mathrm{P}=20.3-1.38 \times \mathrm{A}+2.12 \times \mathrm{B}+0.9 \times \mathrm{AD}-0.9 \times \mathrm{B}^{2}$

In parallel, the reduced model for QP was:

$\mathrm{QP}=1.01-0.15 \times \mathrm{A}+0.21 \times \mathrm{B}+0.05 \times \mathrm{D}+0.08 \times \mathrm{AD}-0.12 \times \mathrm{B}^{2}$ 
The good agreement between the observed values and those predicted by these equations arises from Figure 1. The optimum conditions determined from these models for both variables were very close, so that it was not necessary to define a desirability function for multiple responses: the minimum value of alginate concentration (A) studied, $2 \%$, with a pH (B) of 6.4, close to the maximum value studied. For C and D factors, which played a secondary role, intermediate values of $80 \mathrm{rpm}$ for agitation speed (C) and $4 \%$ for ACEB (D) were retained. The value of lactic acid production corresponding to these parameters was $22.2 \mathrm{~g} / \mathrm{L}$, while productivity was $1.24 \mathrm{~g} / \mathrm{L} / \mathrm{h}$. Experimental runs with these optimal conditions were carried out and the experimental values of $22.1 \pm 0.2 \mathrm{~g} / \mathrm{L}$ and $1.22 \pm 0.08 \mathrm{~g} / \mathrm{L} / \mathrm{h}$ for production and productivity were observed, respectively, which was in very good accordance with the model.

\section{Table 3}

In comparison to Turhan et al.(Turhan et al., 2010a), the initial sugar concentration was between 100-105 g/L sugar because these authors used directly carob pods for sugar extraction, while a waste was used in this work. This explains why fermentation started only with $65 \mathrm{~g} / \mathrm{L}$ sugar, but shows that the waste remains very rich in extractable sugars. As a result, (Turhan et al., 2010a) achieved $31.35 \mathrm{~g} / \mathrm{L}$ lactic acid with a supplemented medium, while it was only $22.1 \mathrm{~g} / \mathrm{L}$ in this work. However, YP/S was only $68.6 \%$ in their study, while $77 \%$ was reached in the present work. As the medium and the microorganism both differ, it is not possible to conclude definitively on the role of immobilization. In addition, sugar utilization was about $44 \%$ in both studies, which shows that immobilization does not significantly change this parameter.

\section{Figure 1}

\section{Table 4}

However, it arises clearly from Table 2 that L. rhamnosus immobilized in alginate beads is able 
to produce effectively lactic acid. But as in Turhan et al.(Turhan et al., 2010a) with L. casei, it seems that L. rhamnosus is only able to use monosaccharides as the substrate, which could explain the high amount of unconsumed sugar at the end of each run in bothstudies.

\subsubsection{Effect of alginate concentration (A)}

Experimental results clearly demonstrate that the increase in alginate concentration has a negative effect on the yield of lactic acid (Fig.2). They show that $2 \%$ leads to a lactic acid concentration of $22 \mathrm{~g} / \mathrm{L}$ and a yield of $77 \%$ (Table 2). Higher concentrations than $2 \%$ alginate may lead to a delay in the consumption of glucose and fructose because it would be more difficult for sugars to percolate into the cell pores (Ercan et al., 2013). As already mentioned, for an or alginate concentration lower than $1 \%$, beads were too soft and were, therefore, easily broken due to their low mechanical strength, thus causing bacteria to leak throughout the beads. These conclusions are consistent with those found by Idris and Suzana(Idris and Suzana, 2006) on the production of lactic acid by Lactobacillus delbrueckii using pineapple waste as substrate. Similarly, Givry et al.(Givry et al., 2008) found a significant difference in the yield of lactic acid obtained by Lactobacillus bifermentans on hemicellulose hydrolyzates with 2 to $4 \%$ alginate. The same results have also been reported by Najafpour et al. (Najafpour et al., 2004)and Ercan et al. (Ercan et al., 2013), but in the production of ethanol. As a conclusion, the results of Table 2 fully agree with the literature and L. rhamnosus displays the same behavior as other microorganisms when immobilization in alginate beads is applied.

\subsubsection{Effect of $p H(B)$}

$\mathrm{pH}$ is a very important parameter in fermentation, as it affects at least two aspects of microbial metabolism: the metabolism of enzymes and the transport of nutrients into the cells (Panesar et al., 2010). In Table 2 and from ANOVA in Table 3, it emerges that it affects significantly lactic acid production, which also emerges in Figure 2. Contrary to alginate 
concentration, both $\mathrm{B}$ and $\mathrm{B}^{2}$ predictors are statistically significant and the coefficient estimates are of opposite sign, which means that a parabolic shape with a maximum is expected. With lactobacilli, the critical $\mathrm{pH}$ value is 4 and the optimal $\mathrm{pH}$ of growth is between 4.5 and 6.4 (Nancib et al., 2001). It is known that when the $\mathrm{pH}$ approaches the $\mathrm{pKa}$ of lactic acid (about 3.9), the undissociated form of lactic acid plays a more inhibitory effect than the dissociated lactate form. At a $\mathrm{pH}$ lower than 5, the undissociated acid form cannot be neglected, whereas a pH greater than 6 leads to almost complete dissociation of lactic acid, which explains why the optimal $\mathrm{pH}$ of fermentation around 6 (Pal et al., 2009). This is in agreement with Figure 2 in which the effect of $\mathrm{pH}$ is stronger between 4.5 and 5.5 than between 5.5 and 6.5. A pH of 5.5 was found by Ghaly et al.(Ghaly et al., 2004) as for the optimum production of lactic acid by L. helveticus. From the results obtained, a pH of 6.4 was found to be the optimal value. This result is close to that of Idris and Suzana (Idris and Suzana, 2006) in which 6.5 was reported to maximize the production of lactic acid by L. delbrueckii. Similarly, Panesar et al.(Panesar et al., 2010) found a maximum conversion rate of lactose and an optimum lactic acid production of $33.5 \mathrm{~g} / \mathrm{L}$ with a pH value of 6.5 . Krischke et al.(Krischke et al., 1991) also reported that a $\mathrm{pH}$ interval between 6.0 and 6.5 is optimal for lactic acid production by Lactobacillus casei. As a conclusion, the optimum $\mathrm{pH}$ observed for immobilized L. rhamnosus is close to the optimum values reported in the literature for similar microorganisms in liquid phase, as expected.

\subsubsection{Effect of agitation rate $(C)$}

Agitation speed is a key parameter for the efficient transfer of nutrients from the bulk to the cells

\section{Figure 2}


in the fermentation process (Liu and Shen, 2008). In this work, Table 3 clearly shows that this factor is not statistically significant. Contradictory results can be found in the literature on this topic. Bai et al.(Bai et al., 2003) reported that lactic acid production increased by $42 \%$ when stirring was increased from 0 to $300 \mathrm{rpm}$. The same conclusion was drawn in Roukas (Roukas, 1994), where alcoholic fermentation on carob juice was enhanced by higher agitation speed. Ercan et al.(Ercan et al., 2013) selected $150 \mathrm{rpm}$ as the optimum agitation rate to produce ethanol from carob bean juice by immobilized Saccharomyces cerevisiae cells. However, Panesar et al.(Panesar et al., 2010) found that there was no difference in the pro- duction of lactic acid between fermentation with and without agitation, in agreement with this work. Finally, this work highlights that contrary to expectations, mass transfer is not the limiting step, even when agitation speed is $50 \mathrm{rpm}$. This shows that immobilization does not slow down lactic fermentation because of mass transfer limitation.

\subsubsection{Effect of $A C E B(D)$}

Based on the results of the experimental design, this parameter does not exhibit a significant effect on the production of lactic acid and has a weak role on productivity (Table 4). However, the interaction $\mathrm{AD}$ with alginate concentration is always significant, which shows that this factor may have a weak non-linear behavior which is not accounted for by the model. In this work, $4 \%$ was retained for the volume of inoculum, which does not exactly fit the optimized values because the optimum is not the same when P and QP are considered. This behavior differs significantly from the other main factors, A and B. ACEB has a slight positive effect on QP, but this is compensated by the AD interaction: when QP is maximized at low $\mathrm{pH}$ (i.e. when $\mathrm{A}$ tends towards -1), the $\mathrm{AD}$ and the $\mathrm{D}$ terms are, therefore, of opposite sign in the QP expression and their sum plays a weak role in the model. Finally, $4 \%$ agrees with the work of Panesar et 
al.(Panesar et al., 2010) in which the maximum concentration of lactic acid was obtained with an inoculum size between 2 and $4 \%$. The increase in inoculum size is supposed to induce an increase in biomass concentration and consumption and production rates, which explains why D has a stronger influence on QP in this work. The reason of an optimum inoculum, volume can be found in Laluce et al.(Laluce et al., 2009) who reported that a high cell density can negatively affect ethanol production due to a lack of nutrients, a limit of space and too strong cell interactions. Similarly, 3\% was the optimal inoculum size for ethanol production by $S$. cerevisiae in Izmirlioglu and Demirci (Izmirlioglu and Demirci, 2012) and in Turhan et al.(Turhan et al., 2010b).

\subsubsection{Effect of the $A D($ Alginate $\times A C E B)$ interaction}

The role of the alginatexACEB interaction has been slightly studied in the literature. Figure 3 illustrates $\mathrm{AD}$ interaction for $\mathrm{P}$ and $\mathrm{QP}$. As already mentioned, the $\mathrm{AD}$ interaction compensates the effect of D in P. For QP, it appears clearly that the effect of D becomes insignificant when $\mathrm{A}=-1$ in Figure 3. More generally, it also arises from this figure that when $\mathrm{A}$ is decreased, D should also be decreased to enhance lactic acid production. Actually, concentrations of alginate higher than $2 \%$ may delay the diffusion of sugars in the beads. So, an increase of alginate concentration requires an increase of the inoculum to maintain the nutrient accessibility to biomass. This explains why the AD interaction is significant both on $\mathrm{P}$ and QP in Table 4.

\subsection{Further improvements of the fermentation process}

\subsubsection{Batch fermentation using UECW}

In order to study whether carob waste juice can be considered as a complete fermentation 
medium, a negative control has been achieved on carob juice without enrichment. Experimental results display a significant difference for the kinetic parameters between the enriched carob waste (ECW) and the unenriched carob waste (UECW) in Table 5. The concentration of lactic acid produced on ECW media was $22 \mathrm{~g} / \mathrm{L}$, whereas this value was only $14 \mathrm{~g} / \mathrm{L}$ for the UECW medium. In addition, there was also a significant difference in maximum production rate: for ECW, QP was $1.22 \mathrm{~g} / \mathrm{L} / \mathrm{h}$, whereas this value was reduced to $0.43 \mathrm{~g} / \mathrm{L} / \mathrm{h}$ for UECW. Similarly, the fermentation of ECW displayed a yield of $77 \%$, while the yield YP/S was decreased to 48.5\% for UECW. This result agrees with the data from Turhan et al.(Turhan et al., 2010a) in which YP/S fell at $41 \%$ without enrichment. This result highlights that the fermentescibility of the carob waste does not differ significantly from that of the fruit, which means that similar nutrients must be added to enhance lactic acid production. As in Turhan et al.(Turhan et al., 2010a), the issue is that carob and, consequently, the carob waste does not contain an adequate nitrogen source. Both contain only proteins (Bahry et al., 2017), while among the nutritional elements, yeast extract was considered essential for Lactobacillus to obtain efficient production of lactic acid (Aeschlimann and Von Stockar, 1990). In the study of Göksungur and Güvenç (Göksungur and Güvenç, 1997), the presence of nitrogen source improved lactic acid production from $10 \mathrm{~g} / \mathrm{L}$ to $60 \mathrm{~g} / \mathrm{L}$. Similarly, Nancib et al.(Nancib et al., 2001) reported that the concentration of lactic acid rose from $30 \pm 2.4 \mathrm{~g} / \mathrm{L}$ without yeast extract, to $46 \mathrm{~g} / \mathrm{L}$ with yeast extract. In addition, manganese ions, a constituent of lactate dehydrogenase, have been shown to have a strong effect on lactic acid production. On date juice, supplementation by yeast extract has been shown to improve production yield, compared to non-enriched date juice (Nancib et al., 2001). Similar conclusions were drawn by Turhan et al. (Turhan et al., 2010a) who compared five nitrogen sources among which the yeast extract maximized the production of lactic acid. Thus, all the kinetic parameters show the need to enrich the culture medium with a source of 
nitrogen and elements that are necessary for the growth of Lactobacillus bacteria. This conclusion can be generalized for Carob pods and carob waste, as similar results were reported concerning the importance of enrichment of culture medium during the production of bioethanol (Bahry et al., 2017; Germec et al., 2015).

\section{Table 5}

\subsubsection{Reusability of alginate beads}

Among the objectives of immobilization, the ability to re-use beads with immobilized cells after replacement of the culture medium is one of the most relevant. For that purpose, repeatedbatch fermentation was carried out to assess the number of possible cycles performed by the immobilized cells while maintaining the stability of the alginate beads. The same optimum fermentation conditions defined in section 3.2 were always applied (2\% alginate, $\mathrm{pH} 6.4$, stirring rate $80 \mathrm{rpm}$ and $\mathrm{ACEB} 4 \%$; total initial sugar concentration: $65 \mathrm{~g} / \mathrm{L}$ ).

From the results obtained in Table 5, cells immobilized in alginate beads can be used for five successive cycles with only a small reduction in yield. At the fifth cycle, the yield decreased by up to $72 \pm 2 \%$, with a small leakage of the cells into the culture medium; this can be explained by the possible combination of lactic acid with phosphate, citrate and calcium ions leading to the disintegration of calcium alginate. However, the P and QP did not significantly change among the fifth run, which highlights that more cycles could probably be applied. This result agrees with Ganguly et al.(Ganguly et al., 2007) who investigated the production of lactic acid with loofa sponge immobilized in Rhizopus oryzae RBU2-10 could be carried out for 10 cycles with a high productivity $(1.66-1.84 \mathrm{~g} / \mathrm{L} / \mathrm{h})$ during the first 5 cycles. Similar results were also reported on ethanol production using Saccharomyces cerevisiae immobilized in alginate by Ercan et al.(Ercan et al., 2013). As a conclusion, this result highlights the interest of L. rhamnosus 
immobilization for lactic acid production.

\subsubsection{Pretreatment of carob juice by invertase enzyme}

In the extracts, the major sugars are glucose, fructose and sucrose. During fermentation with Lactobacillus rhamnosus, glucose and fructose were consumed by the microorganism, whereas sucrose was not metabolized. These results are similar to those found by Nancib et al.(Nancib et al., 2001) using L. rhamnosus and date juice as the substrate. During lactic acid fermentation on pineapple syrup, sucrose was not easily metabolized by Lactococcus lactis because bacteria preferentially used glucose and fructose (Ueno et al., 2003). The same conclusion was drawn by Turhan et al. (Turhan et al., 2010a) using carob juice and L. casei. This may be explained by the fact that enzymes for sucrose catabolism are not synthesized when glucose and fructose exist in the medium, indicating that glucose and fructose have probably caused the repression of sucrose catabolism. In a study involving the simultaneous fermentation of D-xylose and glucose by Candida shehatae, Kastner et al.(Kastner et al., 1998) concluded that glucose inhibits the catabolism of D-xylose by suppressing the induction of D-xylose enzymes. For this purpose, a conversion of sucrose was necessary. As a result, only a pretreatment of the extracts by an invertase enzyme, as in Turhan et al.(Turhan et al., 2010a), was able to lead to the total conversion of sucrose into glucose and fructose and enhance lactic fermentation. Thus, the fermentation was replicated on carob waste juice with a total concentration of reducing sugars of $65 \mathrm{~g} / \mathrm{L}$.

The carob waste juice was treated with an invertase prior to the addition of pre-culture, under optimum conditions previously described. A DNS analysis was performed to validate the total conversion of sucrose into simple sugars. After the pre-culture was added, the fermentation was started by keeping the same optimum conditions of fermentation found by the 
experimental design. The results show that, after treatment with the invertase enzyme, sugar utilization, and lactic acid production and productivity increased up to $92 \%, 40 \mathrm{~g} / \mathrm{L}$ and 1.66 $\mathrm{g} / \mathrm{L} / \mathrm{h}$, compared to $44 \%, 22 \mathrm{~g} / \mathrm{L}$ and $1.2 \mathrm{~g} / \mathrm{L} / \mathrm{h}$ without enzymatic treatment, respectively (Table 6). The yield decreased from $77 \%$ to $66.6 \%$, which shows that increasing sugar concentration promotes biomass growth at the expense of lactic acid productivity. Similar conclusions were drawn by Turhan et al. (Turhan et al., 2010a). Similarly, (Ueno et al., 2003) have improved the production of lactic acid from pineapple waste by Lactococcus lactis after using another invertase enzyme extracted from grape.

\section{Table 6}

As a conclusion, low cost invertase can be used to subsequently enhance sugar utilization, lactic acid production and productivity, but at the expense of yield. This stems from the sugar composition of extracts from carob waste which contains both mono- and disaccharides. The inability of lactic bacteria to ferment at the same time these mono- and disaccharides seems general in the literature, which means that it is favored or repressed neither by the waste, nor by immobilization. Similarly, L. casei and L. rhamnosus display apparently the same behavior, but the reusability of immobilized cells remains a key advantage of this study.

\section{Conclusions}

The solid carob waste resulting from molasses production in the Lebanese food industry is an attractive source to produce lactic acid. Extraction process is able to provide extracts containing $65 \mathrm{~g} / \mathrm{L}$ sugars. However, the enrichment of the culture medium, especially in yeast extract as a nitrogen source, is necessary to significantly increase the yield of lactic acid production at constant sugar utilization. The optimum conditions deduced from response surface methodology lead to a final concentration of lactic acid of $22 \mathrm{~g} / \mathrm{L}$, a yield of $76.9 \%$ and a productivity of $1.22 \mathrm{~g} / \mathrm{L} / \mathrm{h}$. Further improvements included a pretreatment with invertase, so 
that a final concentration of $40 \mathrm{~g} / \mathrm{L}$ and a productivity of $1.66 \mathrm{~g} / \mathrm{L} / \mathrm{h}$ could be achieved, but with

a reduced yield of $66.6 \%$. Immobilization was shown to be an efficient process for the reuse of microorganisms, which allowed an easy separation of the biomass from the liquid phase. The reusability of the beads up to five cycles was demonstrated. A techno-economic analysis must be carried out, now, to optimize the process from sugar extraction to lactic acid purification and determine whether a pre-concentration step of sugar is necessary.

Acknowledgements: This study was supported financially by the Lebanese University and Pascal Institute (France).

\section{REFERENCES}

Aeschlimann, A., Von Stockar, U., 1990. The effect of yeast extract supplementation on the production of lactic acid from whey permeate byLactobacillus helueticus. Appl. Microbiol. Biotechnol. 32, 398-402.

Bahry, H., Pons, A., Abdallah, R., Pierre, G., Delattre, C., Fayad, N., Taha, S., Vial, C., 2017. Valorization of carob waste: Definition of a second-generation bioethanol production process. Bioresour. Technol. 235, 25-34. https://doi.org/10.1016/j.biortech.2017.03.056

Bai, D.-M., Jia, M.-Z., Zhao, X.-M., Ban, R., Shen, F., Li, X.-G., Xu, S.-M., 2003. (+)-lactic acid production by pellet-form Rhizopus oryzae R1021 in a stirred tank fermentor. Chem. Eng. Sci. 58, 785-791.

Box, G.E.P., Behnken, D.W., 1960. Simplex-sum designs: a class of second order rotatable designs derivable from those of first order. Ann. Math. Stat. 31, 838-864.

Dubois, M., Gilles, K.A., Hamilton, J.K., Rebers, P. t, Smith, F., 1956. Colorimetric method for determination of sugars and related substances. Anal. Chem. 28, 350-356.

Ercan, Y., Irfan, T., Mustafa, K., 2013. Optimization of ethanol production from carob pod extract using immobilized Saccharomyces cerevisiae cells in a stirred tank bioreactor. Bioresour. Technol. 135, 365-371.

Ganguly, R., Dwivedi, P., Singh, R.P., 2007. Production of lactic acid with loofa sponge immobilized Rhizopus oryzae RBU2-10. Bioresour. Technol. 98, 1246-1251.

Germec, M., Turhan, I., Karhan, M., Demirci, A., 2015. Ethanol production via repeated-batch fermentation from carob pod extract by using Saccharomyces cerevisiae in biofilm reactor. Fuel 161, 304-311.

Ghaly, A.E., Tango, M.S.A., Mahmoud, N.S., Avery, A.C., 2004. Batch propagation of Lactobacillus helveticus for production of lactic acid from lactose concentrated cheese whey with microaeration and nutrient supplementation. World J. Microbiol. Biotechnol. 20, 65-75.

Givry, S., Prevot, V., Duchiron, F., 2008. Lactic acid production from hemicellulosic hydrolyzate by cells of Lactobacillus bifermentans immobilized in Ca-alginate using response surface methodology. World J. Microbiol. Biotechnol. 24, 745-752. 
Göksungur, Y., Güvenç, U., 1997. Batch and continuous production of lactic acid from beet molasses by Lactobacillus delbrueckii IFO 3202. J. Chem. Technol. Biotechnol. Int. Res. Process Environ. Clean Technol. 69, 399-404.

Haankuku, C., Epplin, F.M., Kakani, V.G., 2015. Industrial sugar beets to biofuel: field to fuel production system and cost estimates. Biomass Bioenergy 80, 267-277.

Haddarah, A., Ismail, A., Bassal, A., Hamieh, T., Ioannou, I., Ghoul, M., 2013. Morphological and chemical variability of Lebanese carob varieties. Eur. Sci. J. ESJ 9.

Idris, A., Suzana, W., 2006. Effect of sodium alginate concentration, bead diameter, initial pH and temperature on lactic acid production from pineapple waste using immobilized Lactobacillus delbrueckii. Process Biochem. 41, 1117-1123.

Izmirlioglu, G., Demirci, A., 2012. Ethanol production from waste potato mash by using Saccharomyces cerevisiae. Appl. Sci. 2, 738-753.

Kastner, J.R., Jones, W.J., Roberts, R.S., 1998. Simultaneous utilization of glucose and D-xylose by Candida shehatae in a chemostat. J. Ind. Microbiol. Biotechnol. 20, 339-343.

Kourkoutas, Y., Xolias, V., Kallis, M., Bezirtzoglou, E., Kanellaki, M., 2005. Lactobacillus casei cell immobilization on fruit pieces for probiotic additive, fermented milk and lactic acid production. Process Biochem. 40, 411-416.

Krischke, W., Schröder, M., Trösch, W., 1991. Continuous production of 1-lactic acid from whey permeate by immobilizedLactobacillus casei subsp. casei. Appl. Microbiol. Biotechnol. 34, 573-578.

Laluce, C., Tognolli, J.O., De Oliveira, K.F., Souza, C.S., Morais, M.R., 2009. Optimization of temperature, sugar concentration, and inoculum size to maximize ethanol production without significant decrease in yeast cell viability. Appl. Microbiol. Biotechnol. 83, 627637.

Limtong, S., Sringiew, C., Yongmanitchai, W., 2007. Production of fuel ethanol at high temperature from sugar cane juice by a newly isolated Kluyveromyces marxianus. Bioresour. Technol. 98, 3367-3374.

Liu, R., Shen, F., 2008. Impacts of main factors on bioethanol fermentation from stalk juice of sweet sorghum by immobilized Saccharomyces cerevisiae (CICC 1308). Bioresour. Technol. 99, 847-854.

Miller, G.L., 1959. Use of dinitrosalicylic acid reagent for determination of reducing sugar. Anal. Chem. 31, 426-428.

Najafpour, G., Younesi, H., Ismail, K.S.K., 2004. Ethanol fermentation in an immobilized cell reactor using Saccharomyces cerevisiae. Bioresour. Technol. 92, 251-260.

Nancib, N., Nancib, A., Boudjelal, A., Benslimane, C., Blanchard, F., Boudrant, J., 2001. The effect of supplementation by different nitrogen sources on the production of lactic acid from date juice by Lactobacillus casei subsp. rhamnosus. Bioresour. Technol. 78, 149153.

Okano, K., Zhang, Q., Yoshida, S., Tanaka, T., Ogino, C., Fukuda, H., Kondo, A., 2010. D-lactic acid production from cellooligosaccharides and $\beta$-glucan using L-LDH gene-deficient and endoglucanase-secreting Lactobacillus plantarum. Appl. Microbiol. Biotechnol. 85, 643-650.

Pal, P., Sikder, J., Roy, S., Giorno, L., 2009. Process intensification in lactic acid production: a review of membrane based processes. Chem. Eng. Process. Process Intensif. 48, 15491559.

Panesar, P.S., Kennedy, J.F., Knill, C.J., Kosseva, M., 2010. Production of L (+) lactic acid using Lactobacillus casei from whey. Braz. Arch. Biol. Technol. 53, 219-226. 
Roukas, T., 1994. Kinetics of ethanol production from carob pods extract by immobilizedSaccharomyces cerevisiae cells. Appl. Biochem. Biotechnol. 44, 49-64.

Sirisansaneeyakul, S., Luangpipat, T., Vanichsriratana, W., Srinophakun, T., Chen, H.H.-H., Chisti, Y., 2007. Optimization of lactic acid production by immobilized Lactococcus lactis IO-1. J. Ind. Microbiol. Biotechnol. 34, 381.

Team, R.C., 2014. R: A language and environment for statistical computing. R Foundation for Statistical Computing, Vienna, Austria. 2013.

Tian, X., Wang, Y., Chu, J., Mohsin, A., Zhuang, Y., 2018. Exploring cellular fatty acid composition and intracellular metabolites of osmotic-tolerant mutant Lactobacillus paracasei NCBIO-M2 for highly efficient lactic acid production with high initial glucose concentration. J. Biotechnol. 286, 27-35.

Turhan, I., Bialka, K.L., Demirci, A., Karhan, M., 2010a. Enhanced lactic acid production from carob extract by Lactobacillus casei using invertase pretreatment. Food Biotechnol. 24, 364-374.

Turhan, I., Bialka, K.L., Demirci, A., Karhan, M., 2010b. Ethanol production from carob extract by using Saccharomyces cerevisiae. Bioresour. Technol. 101, 5290-5296.

Ueno, T., Ozawa, Y., Ishikawa, M., Nakanishi, K., Kimura, T., 2003. Lactic acid production using two food processing wastes, canned pineapple syrup and grape invertase, as substrate and enzyme. Biotechnol. Lett. 25, 573-577.

Yadav, A.K., Chaudhari, A.B., Kothari, R.M., 2011. Bioconversion of renewable resources into lactic acid: an industrial view. Crit. Rev. Biotechnol. 31, 1-19.

ZENGINN, E., SAĞLIKER, H.A., Darici, C., 2008. Carbon mineralization of Ceratonia siliqua L. soils under different temperature and humidity conditions. Turk. J. Bot. 32, 123-127.

Zhao, Z., Xie, X., Wang, Z., Tao, Y., Niu, X., Huang, X., Liu, L., Li, Z., 2016. Immobilization of Lactobacillus rhamnosus in mesoporous silica-based material: An efficiency continuous cell-recycle fermentation system for lactic acid production. J. Biosci. Bioeng. 121, 645651. 
545 Figure 1: Plot of predicted vs. observed P and QP values.

546 Figure 2: Illustration of the influence of alginate concentration and $\mathrm{pH}$ on lactic acid production 547 (Fig.2A) and productivity (Fig. 2B).

548 Figure 3: Interaction plots between alginate concentration and ACEB (D). Effect on: (Fig.3A)

549 Lactic acid production $p(\mathrm{~g} / \mathrm{L})$; (Fig.3B) productivity $\mathrm{Q} p(\mathrm{~g} / \mathrm{L} / \mathrm{h})$.

550

551

552

553

554

555

556

557

558

559

560

561

562

563

564

565

566

567 
Figure 1

569
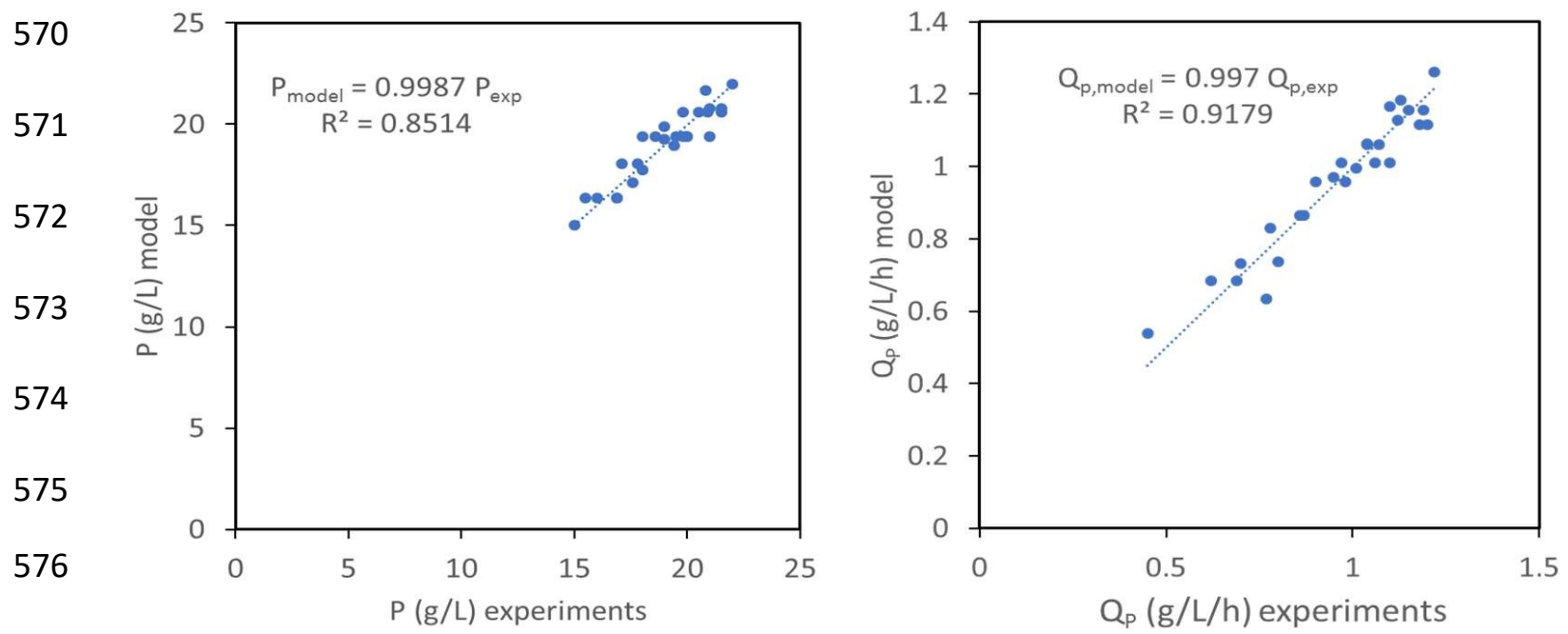

Fig 1.A

Fig 1.B 
Figure 2

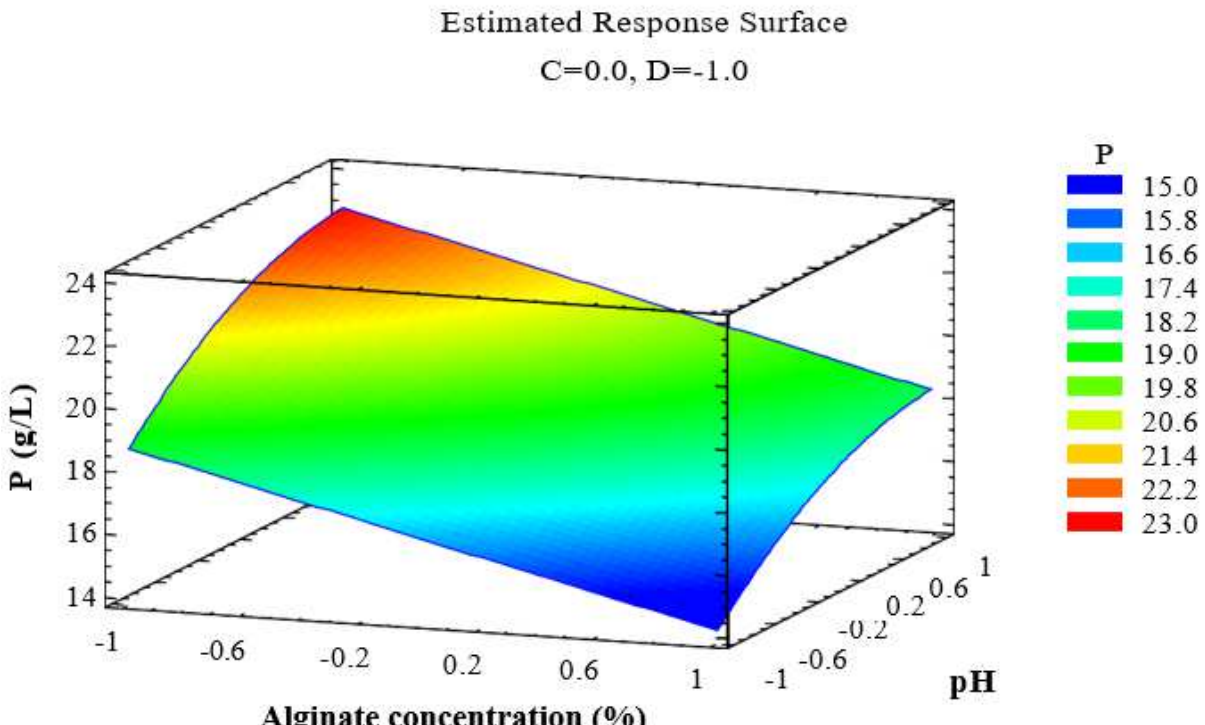

579

Fig 2.A

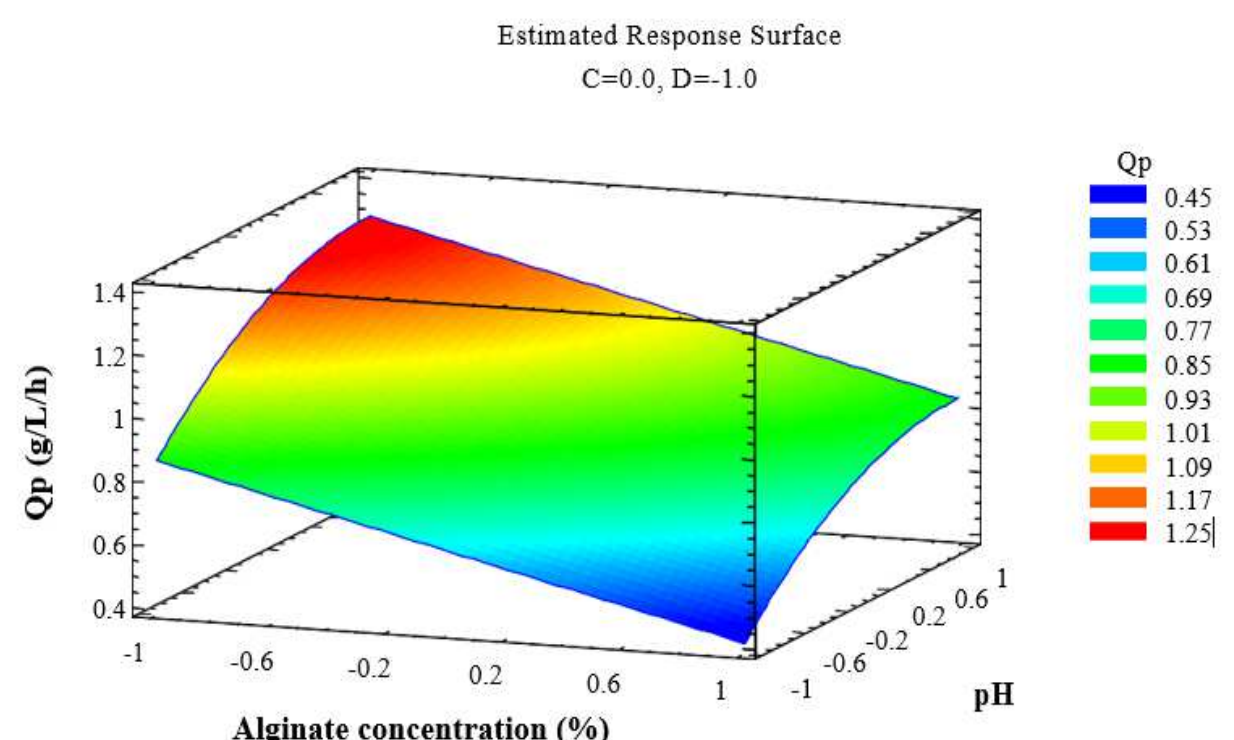


587

Figure 3

588

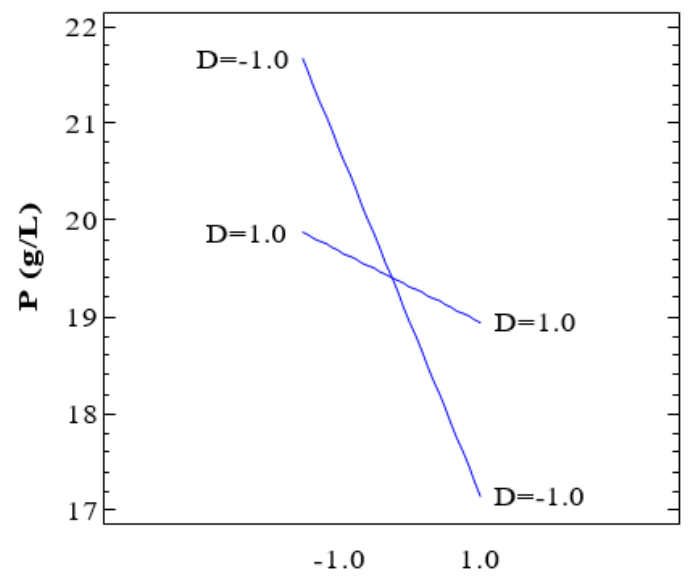

589

Algin ate concentration (\%)

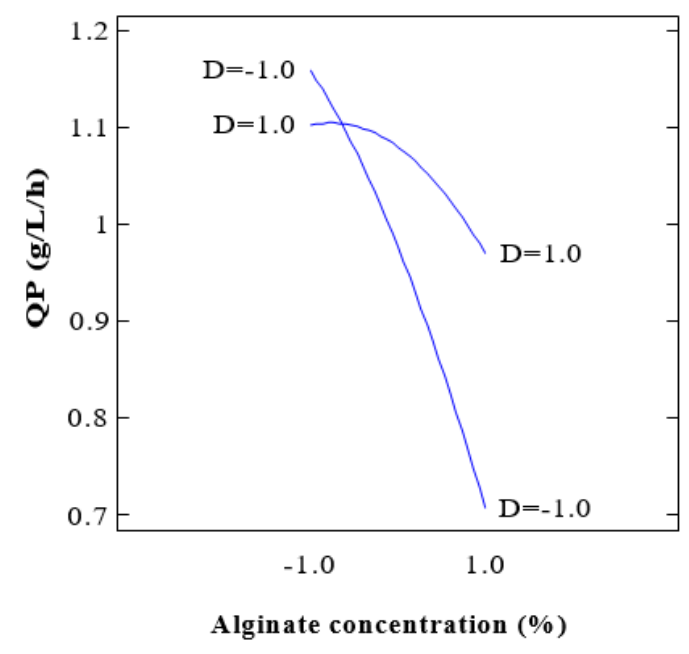

Fig 3.B

592

593

594

595

596

597

598

599

600

601

602

603

604

605

606

607

608

609

610

611

612

613

614

615

616

617

618

619

620

621

Fig 3.A 
623 Table 1. Range and levels of the independent variables in the Box-Behnken design.

624

\begin{tabular}{lcccc}
\hline Factor & Code & -1 & 0 & +1 \\
\hline Alginate concentration (\%) & $\mathrm{A}$ & 2 & 3 & 4 \\
$\mathrm{pH}$ & $\mathrm{B}$ & 4.5 & 5.5 & 6.5 \\
Agitation speed (rpm) & $\mathrm{C}$ & 50 & 100 & 150 \\
ACEB $(\%)$ & $\mathrm{D}$ & 2 & 4 & 6 \\
\end{tabular}

625

626

627

628

629

630

631

632

633

634

635

636

637

638

639

640

641

642

643

644

645

646

647 
648

649

650

651

\begin{tabular}{cccccccc}
\hline Run & $\begin{array}{c}\text { Alginate } \\
\text { concentration } \\
(\%)\end{array}$ & $\mathrm{pH}$ & $\begin{array}{c}\text { Agitation } \\
\text { speed } \\
\text { (rpm) }\end{array}$ & ACEB $(\%)$ & $\mathrm{P}(\mathrm{g} / \mathrm{L})$ & YP/S $(\%)$ & $\mathrm{QP}(\mathrm{g} / \mathrm{L} / \mathrm{h})$ \\
\hline 1 & 0 & 0 & 0 & 0 & 20 & 73.6 & \\
2 & 0 & 0 & 0 & 0 & 21 & 74 & 1.06 \\
3 & 0 & 0 & 0 & 0 & 19.8 & 73.3 & 0.97 \\
4 & -1 & -1 & 0 & 0 & 18 & 72.0 & 0.78 \\
5 & +1 & -1 & 0 & 0 & 15 & 65.2 & 0.45 \\
6 & -1 & +1 & 0 & 0 & 22 & 76.9 & 1.22 \\
7 & +1 & +1 & 0 & 0 & 19 & 76.6 & 0.95 \\
8 & 0 & 0 & -1 & -1 & 18 & 69.2 & 0.90 \\
9 & 0 & 0 & +1 & -1 & 18.6 & 70.0 & 0.98 \\
10 & 0 & 0 & -1 & +1 & 19.52 & 72.3 & 1.04 \\
11 & 0 & 0 & +1 & +1 & 20 & 74.0 & 1.07 \\
12 & -1 & 0 & 0 & -1 & 20.8 & 74.3 & 1.13 \\
13 & +1 & 0 & 0 & -1 & 17.6 & 73.4 & 0.70 \\
14 & -1 & 0 & 0 & +1 & 19 & 67.9 & 1.12 \\
15 & +1 & 0 & 0 & +1 & 19.4 & 77.6 & 1.01 \\
16 & 0 & -1 & -1 & 0 & 15.5 & 62.0 & 0.62 \\
17 & 0 & +1 & -1 & 0 & 21.5 & 75.5 & 1.18 \\
18 & 0 & -1 & +1 & 0 & 16.9 & 70 & 0.69 \\
19 & 0 & +1 & +1 & 0 & 20.5 & 78.8 & 1.20 \\
20 & -1 & 0 & -1 & 0 & 21 & 76.4 & 1.15 \\
21 & +1 & 0 & -1 & 0 & 17.1 & 70.6 & 0.86 \\
22 & -1 & 0 & +1 & 0 & 21.5 & 77.7 & 1.19 \\
23 & +1 & 0 & +1 & 0 & 17.8 & 69.5 & 0.87 \\
24 & 0 & -1 & 0 & -1 & 16.9 & 70.7 & 0.77 \\
25 & 0 & +1 & 0 & -1 & 19.8 & 75.5 & 1.04 \\
26 & 0 & -1 & 0 & +1 & 16 & 64.0 & 0.80 \\
27 & 0 & +1 & 0 & +1 & 20.9 & 76.8 & 1.10 \\
\hline
\end{tabular}

652

653

654

655

656

657

658

659 
Table 3. ANOVA analysis for the three responses (significant p-values are in bold).

\begin{tabular}{|c|c|c|c|c|c|c|}
\hline \multicolumn{2}{|c|}{$\mathrm{P}(\mathrm{g} / \mathrm{L})$} & \multicolumn{4}{|c|}{ YP/S (\%) } & $\mathrm{QP}(\mathrm{g} / \mathrm{L} / \mathrm{h})$ \\
\hline Predictor & $\begin{array}{c}\text { Sum of } \\
\text { Squares }\end{array}$ & $\begin{array}{c}\mathrm{p}- \\
\text { value }\end{array}$ & $\begin{array}{c}\text { Sum of } \\
\text { Squares }\end{array}$ & p-value & $\begin{array}{c}\text { Sum of } \\
\text { Squares }\end{array}$ & p-value \\
\hline $\mathrm{A}$ & 22.4 & 0.0179 & 12.3 & 0.0100 & 0.255 & 0.0169 \\
\hline B & 53.7 & 0.0076 & 262 & 0.0005 & 0.555 & 0.0079 \\
\hline $\mathrm{C}$ & 0.599 & 0.3520 & 16.4 & 0.0075 & 0.00521 & 0.3917 \\
\hline $\mathrm{D}$ & 0.811 & 0.2962 & 0.0234 & 0.7076 & 0.0320 & 0.1150 \\
\hline$A^{2}$ & 1.104 & 0.2438 & 1.75 & 0.0647 & 0.0102 & 0.2684 \\
\hline $\mathrm{AB}$ & 0.000 & 1.0000 & 10.6 & 0.0116 & 0.0009 & 0.6964 \\
\hline $\mathrm{AC}$ & 0.0100 & 0.8907 & 1.45 & 0.0765 & 0.000225 & 0.8427 \\
\hline $\mathrm{AD}$ & 3.24 & 0.1074 & 28.6 & 0.0044 & 0.0256 & 0.1382 \\
\hline $\mathrm{B}^{2}$ & 8.06 & 0.0476 & 7.42 & 0.0165 & 0.0800 & 0.0512 \\
\hline $\mathrm{BC}$ & 1.440 & 0.2029 & 5.45 & 0.0222 & 0.000625 & 0.7434 \\
\hline $\mathrm{BD}$ & 1.00 & 0.2601 & 16.0 & 0.0077 & 0.000225 & 0.8427 \\
\hline $\mathrm{C}^{2}$ & 1.280 & 0.2205 & 4.67 & 0.0258 & 0.000075 & 0.9084 \\
\hline $\mathrm{CD}$ & 0.0036 & 0.9342 & 0.216 & 0.3193 & 0.000625 & 0.7434 \\
\hline $\mathrm{D}^{2}$ & 2.36 & 0.1395 & 4.95 & 0.0244 & 0.0012 & 0.6547 \\
\hline $\begin{array}{c}\text { Lack-of- } \\
\text { fit }\end{array}$ & 4.979 & 0.5361 & 113.393 & 0.0110 & 0.0504 & 0.5552 \\
\hline $\begin{array}{l}\text { Pure } \\
\text { error }\end{array}$ & 0.826 & & 0.2504 & & 0.00886 & \\
\hline $\begin{array}{l}\text { Total } \\
\text { error }\end{array}$ & 97.54 & & 487.32 & & 1.026 & \\
\hline
\end{tabular}

660

661

662

663

664

665

666

667

668

669

670

671

672 
673 Table 4. Summary of ANOVA and coefficient estimates of the reduced models for P and QP,

674 including df (degree of freedom), $\mathrm{p}$ (p-value) and the standard error of the estimates.

675

\begin{tabular}{lccccccc}
\hline \multicolumn{7}{c}{$\mathrm{P}(\mathrm{g} / \mathrm{L})$} \\
\hline Source & Sum of Squares & df & Mean Square & $\mathrm{F}$ & $\mathrm{p}$ & Coefficient & Error \\
\hline $\mathrm{A}$ & 22.4133 & 1 & 22.4133 & 34.03 & 0.0000 & -1.38 & 0.23 \\
$\mathrm{~B}$ & 53.7633 & 1 & 53.7633 & 81.63 & 0.0000 & 2.12 & 0.23 \\
$\mathrm{AD}$ & 3.24 & 1 & 3.24 & 4.92 & 0.0436 & 0.9 & 0.40 \\
$\mathrm{~B}^{2}$ & 5.49643 & 1 & 5.49643 & 8.35 & 0.0119 & -0.9 & 0.31 \\
Lack-of-fit & 3.41657 & 8 & 0.427072 & 0.65 & 0.7265 & & \\
Pure error & 9.2202 & 14 & 0.658586 & & & & \\
Total (corr.) & 97.5499 & 26 & \multicolumn{7}{c}{$\mathrm{QP}(\mathrm{g} / \mathrm{L} / \mathrm{h})$} & & & \\
\hline \multicolumn{7}{c}{} & \multicolumn{7}{c}{$\mathrm{df}$} & Mean Square & $\mathrm{F}$ & $\mathrm{p}$ & Coefficient & Error \\
\hline Source & Sum of Squares & $\mathrm{df}$ & 1 & & \\
\hline $\mathrm{A}$ & 0.255208 & 1 & 0.255208 & 127.47 & 0.0000 & -0.146 & 0.013 \\
$\mathrm{~B}$ & 0.5547 & 1 & 0.5547 & 277.06 & 0.0000 & 0.216 & 0.013 \\
$\mathrm{D}$ & 0.0320333 & 1 & 0.0320333 & 16.00 & 0.0039 & 0.0517 & 0.013 \\
$\mathrm{AD}$ & 0.0256 & 1 & 0.0256 & 12.79 & 0.0072 & 0.08 & 0.023 \\
$\mathrm{~B}^{2}$ & 0.0806667 & 1 & 0.0806667 & 40.29 & 0.0002 & -0.122 & 0.017 \\
Lack-of-fit & 0.0620417 & 13 & 0.00477244 & 2.38 & 0.1107 & & \\
Pure error & 0.0160167 & 8 & 0.00200208 & & & & \\
Total (corr.) & 1.02627 & 26 & & & & & \\
\hline
\end{tabular}

676

677

678

679

680

681

682

683

684

685

686

687

688

689

690

691 
692

693 694

\begin{tabular}{ccllllll}
\hline $\begin{array}{c}\text { Kinetic pa- } \\
\text { rameters }\end{array}$ & $\begin{array}{c}\text { Optimum condition } \\
(\mathrm{ECW})\end{array}$ & $\begin{array}{c}\text { Cycle 1 } \\
(\mathrm{ECW})\end{array}$ & $\begin{array}{c}\text { Cycle 2 } \\
(\mathrm{ECW})\end{array}$ & $\begin{array}{c}\text { Cycle 3 } \\
(\mathrm{ECW})\end{array}$ & $\begin{array}{c}\text { Cycle 4 } \\
(\mathrm{ECW})\end{array}$ & $\begin{array}{c}\text { Cycle 5 } \\
(\mathrm{ECW})\end{array}$ & $\begin{array}{c}\text { Culture on } \\
\text { UECW }\end{array}$ \\
\hline $\begin{array}{c}\text { Sugars } \\
\text { Consumed }\end{array}$ & $29^{\mathrm{a}}$ & $28^{\mathrm{a}}$ & $28.0^{\mathrm{a}}$ & $29^{\mathrm{a}}$ & $28^{\mathrm{a}}$ & $29^{\mathrm{a}}$ & $29^{\mathrm{b}}$ \\
$(\mathrm{g} / \mathrm{L})$ & \pm 1.2 & \pm 4 & \pm 0.9 & \pm 3 & \pm 2 & \pm 4 & \pm 4 \\
Lactic acid & $22^{\mathrm{a}}$ & $22^{\mathrm{a}}$ & $21.4^{\mathrm{a}}$ & $22^{\mathrm{a}}$ & $21^{\mathrm{a}}$ & $20^{\mathrm{a}}$ & $14^{\mathrm{b}}$ \\
$(\mathrm{g} / \mathrm{L})$ & \pm 0.9 & \pm 2 & \pm 0.5 & \pm 4 & \pm 2 & \pm 3 & \pm 3 \\
Yield & $77^{\mathrm{a}}$ & $79^{\mathrm{a}}$ & $76.0^{\mathrm{a}}$ & $75^{\mathrm{a}}$ & $75^{\mathrm{a}}$ & $72^{\mathrm{b}}$ & $49^{\mathrm{c}}$ \\
$(\%)$ & \pm 2 & \pm 4 & \pm 0.9 & \pm 5 & \pm 4 & \pm 3 & \pm 3 \\
Production & $1.22^{\mathrm{a}}$ & $1.16^{\mathrm{a}}$ & $1.2^{\mathrm{a}}$ & $1.1^{\mathrm{a}}$ & $1.2^{\mathrm{a}}$ & $1.2^{\mathrm{a}}$ & $0.43^{\mathrm{b}}$ \\
rate $(\mathrm{g} / \mathrm{L} / \mathrm{h})$ & \pm 0.08 & \pm 0.02 & \pm 0.6 & \pm 0.1 & \pm 0.9 & \pm 0.3 & \pm 0.08
\end{tabular}

695

696

697

698

699

700

701

702

703

704

705

706

707

708

709

710

711

712

Table 5. Evolution of kinetic parameters of lactic acid production when recycling alginate beads

In each line, the same superscript letter within columns indicates homogeneous subset. 
713 Table 6. Kinetic parameters of lactic acid production from carob waste (CW)

714 and carob waste treated with invertase enzyme(CWI).

715

\begin{tabular}{lcc}
\hline Kinetic parameters & CW & CWI \\
\hline Initial sugar concentration $(\mathrm{g} / \mathrm{L})$ & $65^{\mathrm{a}}$ & $65^{\mathrm{a}}$ \\
Sugars consumed $(\mathrm{g} / \mathrm{L})$ & $28.6^{\mathrm{a}}$ & $60^{\mathrm{b}}$ \\
Lactic acid produced, $\mathrm{P}(\mathrm{g} / \mathrm{L})$ & $22^{\mathrm{a}}$ & $40^{\mathrm{b}}$ \\
Yield, $\mathrm{P}(\%)$ & $76.9^{\mathrm{a}}$ & $66.6^{\mathrm{b}}$ \\
Max production rate, QP $(\mathrm{g} / \mathrm{L} / \mathrm{h})$ & $1.22^{\mathrm{a}}$ & $1.66^{\mathrm{b}}$ \\
\hline
\end{tabular}

716

In each line, the same superscript letter within columns indicates homogeneous subset. 